\title{
Combinatorial doping of $\mathrm{TiO}_{2}$ with platinum (Pt), chromium $(\mathrm{Cr})$, vanadium $(\mathrm{V})$, and nickel $(\mathrm{Ni})$ to achieve enhanced photocatalytic activity with visible light irradiation
}

\author{
Jina Choi \\ W.M. Keck Laboratories, California Institute of Technology, Pasadena, California 91125 \\ Hyunwoong Park \\ School of Physics and Energy Science, Kyungpook National University, Daegu 702-701, South Korea \\ Michael R. Hoffmann ${ }^{\text {a) }}$ \\ W.M. Keck Laboratories, California Institute of Technology, Pasadena, California 91125
}

(Received 19 May 2009; accepted 2 July 2009)

\begin{abstract}
Titanium dioxide $\left(\mathrm{TiO}_{2}\right)$ was doped with the combination of several metal ions including platinum (Pt), chromium (Cr), vanadium (V), and nickel (Ni). The doped $\mathrm{TiO}_{2}$ materials were synthesized by standard sol-gel methods with doping levels of 0.1 to 0.5 at.\%. The resulting materials were characterized by x-ray diffraction (XRD), BET surface-area measurement, scanning electron microscopy (SEM), and UV-vis diffuse reflectance spectroscopy (DRS). The visible light photocatalytic activity of the codoped samples was quantified by measuring the rate of the oxidation of iodide, the rate of degradation of methylene blue (MB), and the rate of oxidation of phenol in aqueous solutions at $\lambda>$ $400 \mathrm{~nm} .0 .3$ at.\% $\mathrm{Pt}-\mathrm{Cr}-\mathrm{TiO}_{2}$ and 0.3 at. $\% \mathrm{Cr}-\mathrm{V}-\mathrm{TiO}_{2}$ showed the highest visible light photocatalytic activity with respect to $\mathrm{MB}$ degradation and iodide oxidation, respectively. However, none of the codoped $\mathrm{TiO}_{2}$ samples were found to have enhanced photocatalytic activity for phenol degradation when compared to their single-doped $\mathrm{TiO}_{2}$ counterparts.
\end{abstract}

\section{INTRODUCTION}

Titania $\left(\mathrm{TiO}_{2}\right)$ is the most widely used photocatalyst for the purification of water, air, and other environmental applications because of its high photocatalytic activity, excellent chemical stability, relatively low price, and its lack of any known toxicity. Redox reactions of environmental interest are initiated on the $\mathrm{TiO}_{2}$ surface with trapped electrons and holes after band gap excitation. However, because of its wide band gap energy of $\sim 3.2 \mathrm{eV}$, $\mathrm{TiO}_{2}$ is active only in the ultraviolet portion of the solar spectrum. As a consequence, significant efforts have been made to develop modified forms of $\mathrm{TiO}_{2}$ that are active under visible light irradiation $(\lambda>400 \mathrm{~nm})$. Several different strategies have been used to extend photoactivity into the visible region. They include (i) doping with anions (e.g., nitrogen, ${ }^{1-3}$ sulfur, ${ }^{4}$ iodine, ${ }^{5-7}$ and fluorine ${ }^{8}$ ), (ii) doping with metal ions, ${ }^{9-18}$ and (iii) functionalizing $\mathrm{TiO}_{2}$ with photosensitizers that absorb visible light. ${ }^{19,20}$

The most actively pursued strategy has been to increase the photoactive wavelength range and to enhance the photocatalytic activity under UV irradiation by metal ion doping of $\mathrm{TiO}_{2} \cdot{ }^{21-23}$ Numerous metal ions have been

\footnotetext{
a) Address all correspondence to this author.

e-mail:mrh@caltech.edu

DOI: 10.1557/JMR.2010.0024
}

investigated as potential dopants while several metal ions such as iron, ${ }^{9-11}$ vanadium, ${ }^{12-14}$ chromium, ${ }^{15,16}$ nickel, ${ }^{17}$ and platinum ${ }^{18}$ have been reported to show visible light photocatalytic activity.

In addition, efforts have been made to improve the visible light photocatalytic activity of $\mathrm{TiO}_{2}$ by codoping with two metal ions. ${ }^{24-28}$ Ahmad et al. reported that $\mathrm{Sc}$ and $\mathrm{Nb}$ codoped $\mathrm{TiO}_{2}$ nanoparticles are relatively more photoactive for 2-chlorophenol degradation under visible light than the particles doped with $\mathrm{Sc}$ or $\mathrm{Nb}$ alone. ${ }^{25}$ Kato and Kudo showed that $\mathrm{TiO}_{2}$ codoped with $\mathrm{Sb}^{5+}$ and $\mathrm{Cr}^{3+}$ ions showed higher activity than $\mathrm{TiO}_{2}$ doped only with $\mathrm{Cr}^{3+}$ ions alone for $\mathrm{O}_{2}$ evolution because of the charge compensation achieved with $\mathrm{Sb}^{5+}$ doping. ${ }^{26}$ Furthermore, $\mathrm{TiO}_{2}$ codoped with $\mathrm{Ni}^{2+}$ and $\mathrm{Ta}^{5+}$ (or $\mathrm{Ni}^{2+}$ and $\mathrm{Nb}^{5+}$ ) and $\mathrm{TiO}_{2}$ codoped with $\mathrm{Rh}^{3+}$ and $\mathrm{Sb}^{5+}$ were also shown to improve photocatalytic activity for $\mathrm{O}_{2}$ evolution under visible light irradiation. ${ }^{27,28}$ However, there have been relatively few studies reported for double metal ion codoping of $\mathrm{TiO}_{2}$, while $\mathrm{TiO}_{2}$ codoped with two nonmetallic elements (e.g., $\mathrm{N}$ and $\mathrm{F}$ codoping, ${ }^{29,30} \mathrm{~N}$ and $\mathrm{S}$ codoping ${ }^{31,32}$ ) or with metal ions and nonmetallic elements ${ }^{33-39}$ (e.g., $\mathrm{Cr}$ and $\mathrm{N}$ codoping ${ }^{35}$ $\mathrm{Pt}$ and $\mathrm{N}$ codoping, ${ }^{36} \mathrm{~V}$ and $\mathrm{N}$ codoping, ${ }^{37}$ and $\mathrm{Bi}$ and $\mathrm{S}$ codoping ${ }^{38}$ ) have been widely investigated.

To examine the efficacy of double-doping with metal ions, we have prepared codoped $\mathrm{TiO}_{2}$ with $\mathrm{Pt}^{4+}\left(\right.$ or $\left.\mathrm{Pt}^{2+}\right)$, 
$\mathrm{Cr}^{3+}, \mathrm{V}^{3+}$, and $\mathrm{Ni}^{2+}$ ions and characterized their physicochemical properties and photocatalytic activities for the bleaching and degradation of methylene blue (MB), the oxidation of iodide to tri-iodide, and the oxidative degradation of phenol in aqueous solution under visible light irradiation $(\lambda>400 \mathrm{~nm})$.

\section{EXPERIMENTAL}

\section{A. Sample preparation}

$\mathrm{TiO}_{2}$ nanoparticles were prepared by standard sol-gel methods. $5.0 \mathrm{~mL}$ of titanium tetraisopropoxide (TTIP, Aldrich, St. Louis, MO) was dissolved in $50 \mathrm{~mL}$ of absolute ethanol (Mallinckrodt, Phillipsburg, NJ) and then added dropwise to $50 \mathrm{~mL}$ of distilled water adjusted to $\mathrm{pH} 1.5$ with nitric acid under vigorous stirring at room temperature. After $24 \mathrm{~h}$, the resulting transparent colloidal suspensions were evaporated using a rotary evaporator at $45^{\circ} \mathrm{C}$ and dried in the oven $\left(70{ }^{\circ} \mathrm{C}\right)$ overnight. The resulting powders were calcined at $400{ }^{\circ} \mathrm{C}$ for $1 \mathrm{~h}$ under air. Single or double-doped $\mathrm{TiO}_{2}$ samples $\left(\mathrm{M}-\mathrm{TiO}_{2}\right.$ or $\mathrm{MM}$ $\mathrm{TiO}_{2}$ ) were prepared by adding one or two metal precursors to the distilled water prior to the hydrolysis of TTIP to give a doping level from 0.1 to 0.5 at.\%. Platinum ( $\mathrm{Pt}^{4+}$ and $\left.\mathrm{Pt}^{2+}\right)$, chromium $\left(\mathrm{Cr}^{3+}\right)$, vanadium $\left(\mathrm{V}^{3+}\right)$, and nickel $\left(\mathrm{Ni}^{2+}\right)$ were selected as metal-ion dopants in this study. $\mathrm{PtCl}_{4}$ (Aldrich), $\mathrm{Pt}\left(\mathrm{NH}_{3}\right)_{4}\left(\mathrm{NO}_{3}\right)_{2}$ (Alfar Aesar, Ward Hill, $\mathrm{MA}$ ), $\mathrm{Cr}\left(\mathrm{NO}_{3}\right)_{3} \cdot 9 \mathrm{H}_{2} \mathrm{O}$ (Aldrich), $\mathrm{VCl}_{3}$ (Aldrich), and $\mathrm{Ni}\left(\mathrm{NO}_{3}\right)_{2} \cdot 6 \mathrm{H}_{2} \mathrm{O}$ (Alfar Aesar) were used as precursor reagents. Six different $\mathrm{TiO}_{2}$ samples were synthesized and codoped with (i) $\mathrm{Pt}^{4+}$ and $\mathrm{Cr}^{3+}$ ions $\left[\mathrm{Pt}(\mathrm{IV})-\mathrm{Cr}-\mathrm{TiO}_{2}\right]$, (ii) $\mathrm{Pt}^{2+}$ and $\mathrm{Cr}^{3+}$ ions $\left[\mathrm{Pt}(\mathrm{II})-\mathrm{Cr}-\mathrm{TiO}_{2}\right]$, (iii) $\mathrm{Cr}^{3+}$ and $\mathrm{V}^{3+}$ ions $\left(\mathrm{Cr}-\mathrm{V}-\mathrm{TiO}_{2}\right)$, (iv) $\mathrm{Pt}^{2+}$ and $\mathrm{V}^{3+}$ ions $\left[\mathrm{Pt}(\mathrm{II})-\mathrm{V}-\mathrm{TiO}_{2}\right.$, (v) $\mathrm{Pt}^{2+}$ and $\mathrm{Ni}^{2+}$ ions [Pt(II)-Ni-TiO ${ }_{2}$, and (vi) $\mathrm{Cr}^{3+}$ and $\mathrm{Ni}^{2+}$ ions $\left(\mathrm{Cr}-\mathrm{Ni}-\mathrm{TiO}_{2}\right)$. In addition, a control sample without doping was prepared along with singly-doped $\mathrm{TiO}_{2}$ [i.e., $\mathrm{Pt}(\mathrm{IV})-\mathrm{TiO}_{2}, \mathrm{Pt}(\mathrm{II})-\mathrm{TiO}_{2}, \mathrm{Cr}-\mathrm{TiO}_{2}, \mathrm{~V}-\mathrm{TiO}_{2}$, and $\mathrm{Ni}-\mathrm{TiO}_{2}$ ] for comparison with codoped $\mathrm{TiO}_{2}$.

\section{B. Characterization}

We used x-ray diffraction (XRD) to examine the crystal structures of synthesized $\mathrm{TiO}_{2}$ particles by using a Philips diffractometer (X'pert Pro) with $\mathrm{Cu}-\mathrm{K} \alpha$ radiation. Brunauer-Emmett-Teller (BET) surface area measurement was carried out by using $\mathrm{N}_{2}$ as the adsorptive gas (Micromeritics Gemini series, Norcross, GA). Scanning electron microscopic images (SEM, LEO 1550VP model, Peabody, MA) were taken to investigate the morphology of $\mathrm{TiO}_{2}$ particles and analysis of elemental composition was also performed with EDS (energy dispersive $\mathrm{X}$-ray spectroscopy). Diffuse reflectance UV-vis absorption spectra (DRS) of powder samples were obtained using a UV-vis spectrometer (Shimadzu UV-2101PC, Columbia, $\mathrm{MD}$ ) equipped with a diffuse reflectance accessory.

\section{Photocatalytic activity measurements}

The photocatalytic activity of the synthesized $\mathrm{TiO}_{2}$ samples was quantified with respect to the rates of photobleaching and degradation of methylene blue (MB), the rates of oxidation of iodide $\left(\mathrm{I}^{-}\right)$, and the rates of oxidative degradation of phenol $(\mathrm{PhOH})$. The individual photocatalyst powders were dispersed in distilled water to give a mass concentration of $1 \mathrm{gL}^{-1}$. An aliquot of the target substrate stock solution was then added to the catalyst suspension to give the specific substrate concentration (e.g., $[\mathrm{MB}]_{0}=10 \mu \mathrm{M},\left[\mathrm{I}^{-}\right]_{0}=50 \mathrm{mM}$, and $\left.[\mathrm{PhOH}]_{0}=50 \mu \mathrm{M}\right)$. The reaction suspension $\mathrm{pH}$ was circum-neutral. Before irradiation, the suspension was stirred in the dark for $30 \mathrm{~min}$ to obtain a state of sorption equilibrium of the specific substrate on $\mathrm{TiO}_{2}$.

A high-pressure $\mathrm{Hg}(\mathrm{Xe})$ arc lamp $(500 \mathrm{~W})$ was used as the light source. The light beam emitted from the arc lamp was passed through an IR water filter and a UV cut-off filter $(\lambda>400 \mathrm{~nm})$ before being focused onto a cylindrical Pyrex reactor through a quartz window. The reactor was open to ambient air during most experiments. Time-sequenced sample aliquots were collected from the reactor during the illumination for analysis and filtered through a $0.45 \mu \mathrm{m}$ PTFE syringe filter to remove the $\mathrm{TiO}_{2}$ particles. Multiple photolysis (and photocatalysis) experiments were performed under identical reaction conditions to determine reproducibility.

The degradation rates and rate constants for MB loss during photocatalysis were determined by measuring the absorbance of MB at $665 \mathrm{~nm}$ with a spectrophotometer (Shimadzu UV-2101PC). For the photocatalytic oxidation of $\mathrm{I}^{-}$, tri-iodide $\left(\mathrm{I}_{3}{ }^{-}\right)$, which is the principal product of $\mathrm{I}^{-}$oxidation in the presence of excess iodide ion, was spectrophotometrically determined by measuring the absorbance at $352 \mathrm{~nm}$. The degradation of phenol in aqueous solution was measured using high-performance liquid chromatography (HPLC, Agilent HP 1100 series with C18 column, Santa Clara, CA).

\section{RESULTS AND DISCUSSION}

\section{A. Characterization of single metal doped $\mathrm{TiO}_{2}$ $\left(\mathrm{M}-\mathrm{TiO}_{2}\right)$}

Singly-doped $\mathrm{TiO}_{2}\left(\mathrm{M}-\mathrm{TiO}_{2}\right)$ samples were prepared by sol-gel synthesis where $\mathrm{M}=\mathrm{Pt}^{4+}, \mathrm{Cr}^{3+}, \mathrm{V}^{3+}$, and $\mathrm{Ni}^{2+}$. To compare the effect of oxidation state of $\mathrm{Pt}$ dopant, $\mathrm{TiO}_{2}$ doped with $\mathrm{Pt}^{2+}$ ions was also prepared. Figure 1 shows the XRD patterns of the singly-doped $\mathrm{M}-\mathrm{TiO}_{2}$ samples at the doping level of 0.3 at.\%. The XRD patterns are consistent with the standard crystal structure of $\mathrm{TiO}_{2}$ (i.e., a mixture of anatase and rutile phases) with no diffraction peaks associated with any of the doped metal elements in the $\mathrm{M}-\mathrm{TiO}_{2}$ samples. This indicates that the doping process does not induce the formation of separate impurity 


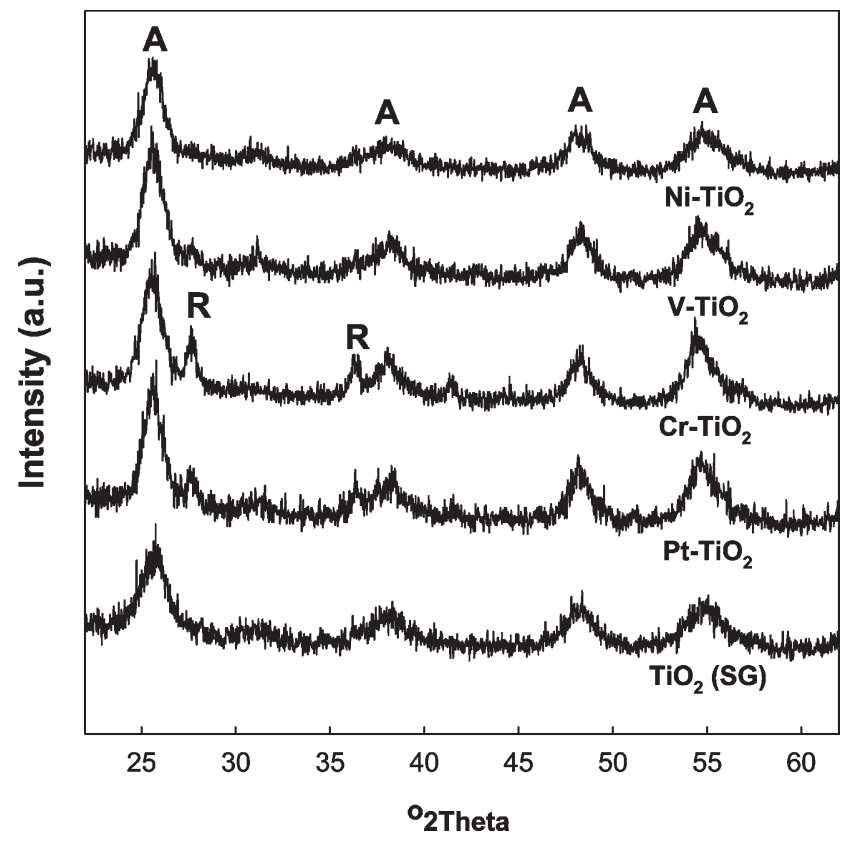

FIG. 1. X-ray diffraction (XRD) pattern measured for 0.3 at.\% $\mathrm{M}-\mathrm{TiO}_{2}$ prepared at $400{ }^{\circ} \mathrm{C}$ (A: anatase phase, $\mathrm{R}$ : rutile phase).

phases and that the specific dopant could be considered to be fully incorporated into the $\mathrm{TiO}_{2}$ lattice. $\mathrm{Pt}^{4+}, \mathrm{Cr}^{3+}$, and $\mathrm{V}^{3+}$ ions may be substituted into the Ti site of $\mathrm{TiO}_{2}$ because the ionic radii of the dopants $\left(\mathrm{Pt}^{4+}: 0.765 \AA, \mathrm{Cr}^{3+}\right.$ : $0.755 \AA$, and $\left.\mathrm{V}^{3+}: 0.78 \AA\right)^{40}$ are similar to that of $\mathrm{Ti}^{4+}$ $(0.745 \AA) .{ }^{40}$ However, $\mathrm{Ni}^{2+}$ and $\mathrm{Pt}^{2+}$ ions are possibly located in the interstitial position of the lattice rather than the $\mathrm{Ti}$ site because of the relatively large size difference between the dopant ions $\left(\mathrm{Ni}^{2+}: 0.83 \AA \text { and } \mathrm{Pt}^{2+}: 0.94 \AA\right)^{40}$ and the $\mathrm{Ti}^{4+}$ ions. Undoped $\mathrm{TiO}_{2}$ samples prepared by solgel synthesis and calcined at $400{ }^{\circ} \mathrm{C}\left(\mathrm{TiO}_{2}\right.$-SG) show only the pure anatase phase. However, the rutile phase is apparent in some $\mathrm{M}-\mathrm{TiO}_{2}$ samples prepared and treated at the same temperature. This result suggests that metal-ion doping lowers the relative temperature of the anatase-torutile phase transformation (A-R phase transformation). 0.3 at. $\% \mathrm{Cr}-\mathrm{TiO}_{2}$ and 0.3 at. $\%$ Pt-TiO 2 [both $\mathrm{Pt}(\mathrm{IV})-\mathrm{TiO}_{2}$ and $\mathrm{Pt}(\mathrm{II})-\mathrm{TiO}_{2}$ ] exhibit a characteristic rutile peak whereas 0.3 at. $\%{\mathrm{~V}-\mathrm{TiO}_{2}}_{2}$ appear to have a smaller fraction of the rutile phase. 0.3 at. $\% \mathrm{Ni}-\mathrm{TiO}_{2}$, by contrast, shows a pure anatase phase as in the case of undoped $\mathrm{TiO}_{2}$. Therefore, we conclude that doping $\mathrm{TiO}_{2}$ with $\mathrm{Cr}$, $\mathrm{Pt}$, and $\mathrm{V}$ ions modifies the temperature dependence of the A-R phase transformation.

Figure 2 shows the UV/vis diffuse reflectance spectra for the various $\mathrm{M}-\mathrm{TiO}_{2}$ samples. Undoped $\mathrm{TiO}_{2}$ exhibits a sharp absorption edge at about $400 \mathrm{~nm}\left(E_{\mathrm{bg}} \approx 3.1 \mathrm{eV}\right)$. However, the $\mathrm{M}-\mathrm{TiO}_{2}$ samples show absorption spectra extended into the visible region over the range of 400$700 \mathrm{~nm}$. Thus, visible light activation and photocatalytic activity could be expected from these $\mathrm{M}-\mathrm{TiO}_{2}$ samples.
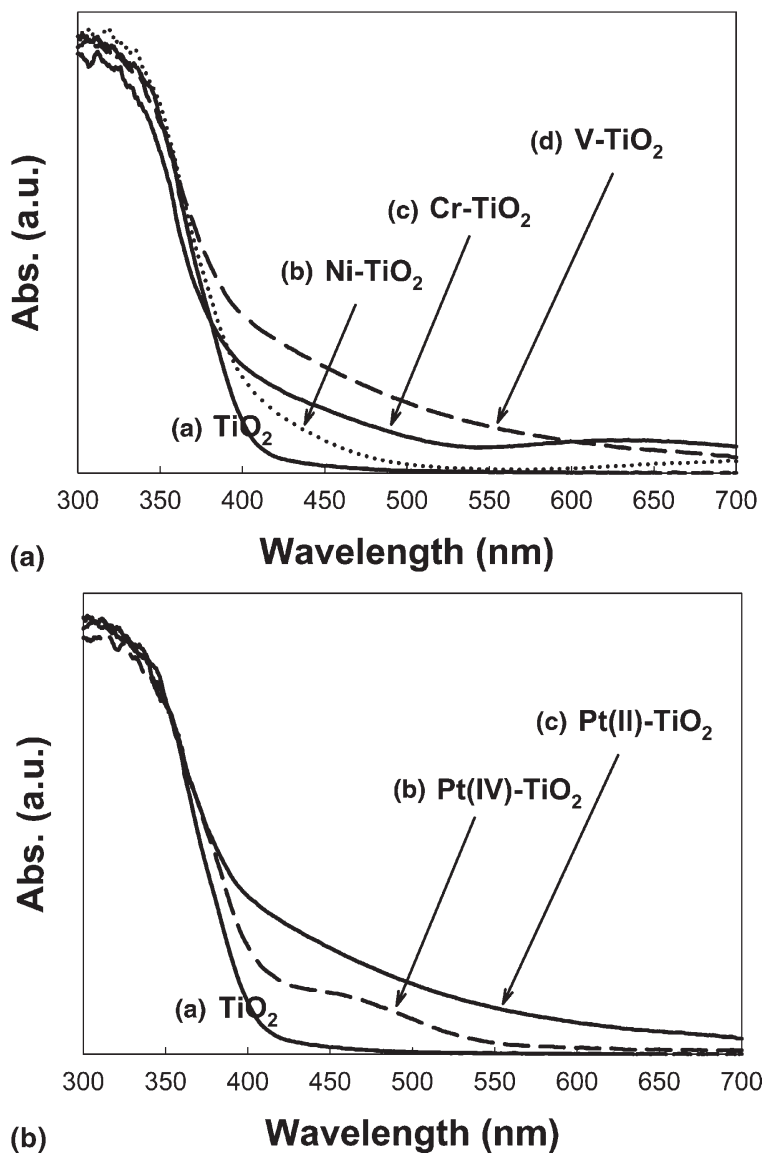

FIG. 2. UV/vis diffuse reflectance spectra (DRS) for 0.3 at. $\%$ M-TiO ${ }_{2}$ samples: (a) undoped $\mathrm{TiO}_{2}, \mathrm{Cr}-\mathrm{TiO}_{2}, \mathrm{Ni}-\mathrm{TiO}_{2}$, and $\mathrm{V}-\mathrm{TiO}_{2}$. (b) $\mathrm{Pt}(\mathrm{IV})-\mathrm{TiO}_{2}$ and $\mathrm{Pt}(\mathrm{II})-\mathrm{TiO}_{2}$.

As shown in Fig. 2(a), 0.3 at. $\% \mathrm{Ni}^{-\mathrm{TiO}_{2}}$ gives a relatively small absorption between 400 and $500 \mathrm{~nm}$ while 0.3 at. $\% \mathrm{~V}^{-} \mathrm{TiO}_{2}$ exhibits a more substantial and broader absorption shoulder up to $700 \mathrm{~nm} .0 .3$ at. $\% \mathrm{Cr}^{-\mathrm{TiO}_{2}}$ also shows extended absorption spectra over the $400-500 \mathrm{~nm}$ range with an additional absorption peak near $650 \mathrm{~nm}$; this may be due to the $d$ - $d$ transitions of $\mathrm{Cr}^{3+}$ ions. ${ }^{26,41}$ Figure 2(b) shows the difference between the absorption spectra of 0.3 at. $\% \mathrm{Pt}(\mathrm{IV})-\mathrm{TiO}_{2}$ and 0.3 at. $\% \mathrm{Pt}(\mathrm{II})-\mathrm{TiO}_{2}$. $\mathrm{Pt}(\mathrm{II})-\mathrm{TiO}_{2}$ gives a broad absorption over most of the visible region similar to 0.3 at. $\% \mathrm{~V}^{-}-\mathrm{TiO}_{2}$. In contrast, 0.3 at. $\% \mathrm{Pt}(\mathrm{IV})-\mathrm{TiO}_{2}$ gives a smaller absorption peak between 400 and $550 \mathrm{~nm}$; this indicates that the origins of the absorption spectra are different in the two different $\mathrm{Pt}-\mathrm{TiO}_{2}$ samples. The extended absorption of the $\mathrm{M}-\mathrm{TiO}_{2}$ into the visible region has been explained in terms of the excitation of electrons of the dopant ion to the $\mathrm{TiO}_{2}$ conduction band (i.e., a metal to conduction band charge transfer) according to their respective energy levels. ${ }^{12,13,42,43}$ However, recent proposals suggest that the absorption spectra of modified $\mathrm{TiO}_{2}$ in the visible region most likely originate from defects associated with oxygen vacancies that give rise to colored 
centers. ${ }^{44,45}$ Kuznetsov and Serpone pointed out the similarities of the spectra in the range of $400-600 \mathrm{~nm}$ shown among different types of visible light active $\mathrm{TiO}_{2}$ samples. ${ }^{44}$ It was also reported that similar absorption spectra in the visible region are found in reduced $\mathrm{TiO}_{2}$ samples with observed absorption spectra being the sum of overlapping absorption bands with the maxima at $2.81 \mathrm{eV}$ and $2.55 \mathrm{eV}$, which correlate with oxygen vacancies. $^{46,47}$ The metal-ion dopants used in this study have different valence states than $\mathrm{Ti}^{4+}$, and as a consequence, may induce the generation of oxygen vacancies during synthesis. In addition, some of the $\mathrm{M}-\mathrm{TiO}_{2}$ samples [e.g., Ni- $\mathrm{TiO}_{2}, \mathrm{~V}-\mathrm{TiO}_{2}, \mathrm{Pt}(\mathrm{II})-\mathrm{TiO}_{2}$ ] exhibit similar absorption in the range of $400-600 \mathrm{~nm}$, even though the absorption intensities are different. Therefore, both the generation of new energy levels due to the injection of impurities within the band gap energies range and the generation of oxygen vacancies by metal doping may contribute to the observed visible light absorption of $\mathrm{M}-\mathrm{TiO}_{2}$ samples.

\section{B. Characterization of metal codoped $\mathrm{TiO}_{2}\left(\mathrm{MM}-\mathrm{TiO}_{2}\right)$}

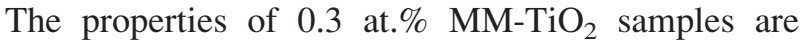
summarized in Table I. The doubly-doped $\mathrm{MM}-\mathrm{TiO}_{2}$ samples exhibit a variety of colors; $\mathrm{TiO}_{2}$ samples doped with $\mathrm{Cr}$ or $\mathrm{Ni}$ are green; $\mathrm{Pt}$ doped samples are brown; and $\mathrm{V}$ doped samples are orange. The BET surface area of the sol-gel synthesized, undoped $\mathrm{TiO}_{2}$, which was calcined at $400{ }^{\circ} \mathrm{C}$, is $104 \mathrm{~cm}^{2} / \mathrm{g}$ whereas the surface area of the Degussa $\mathrm{P} 25 \mathrm{TiO}_{2}$ is $50 \mathrm{~cm}^{2} / \mathrm{g}$, indicating that the $\mathrm{TiO}_{2}$ particles synthesized by sol-gel methods have substantially higher surface areas and adsorption capacities per unit weight than Degussa P25. The surface areas of 0.3 at. $\% \mathrm{M}-\mathrm{TiO}_{2}$ samples are slightly larger than the undoped $\mathrm{TiO}_{2}\left(106-132 \mathrm{~cm}^{2} / \mathrm{g}\right)$. However, there are no significant increases in the surface areas of doublydoped samples $\left(\sim 110 \mathrm{~cm}^{2} / \mathrm{g}\right)$.

TABLE I. Characterization of $\mathrm{MM}-\mathrm{TiO}_{2}$ photocatalysts at 0.3 at. $\%$ doping level.

\begin{tabular}{|c|c|c|c|}
\hline Sample & Color & $\begin{array}{c}\text { Surface } \\
\text { area }\left(\mathrm{m}^{2} \mathrm{~g}^{-1}\right)\end{array}$ & $\begin{array}{l}\text { Crystal structure } \\
\qquad\left(\mathrm{X}_{\mathrm{R}} \%\right)\end{array}$ \\
\hline $\mathrm{TiO}_{2}(\mathrm{SG})$ & White & 104 & Anatase (0) \\
\hline $\mathrm{Pt}(\mathrm{II})-\mathrm{TiO}_{2}$ & Light brown & 111 & Anatase/Rutile (22) \\
\hline $\mathrm{Pt}(\mathrm{IV})-\mathrm{TiO}_{2}$ & Light brown & 106 & Anatase/Rutile (26) \\
\hline $\mathrm{Cr}-\mathrm{TiO}_{2}$ & Green & 115 & Anatase/Rutile (34) \\
\hline $\mathrm{V}-\mathrm{TiO}_{2}$ & Orange & 132 & Anatase/Rutile (13) \\
\hline $\mathrm{Ni}-\mathrm{TiO}_{2}$ & Green & 112 & Anatase (0) \\
\hline $\mathrm{Pt}(\mathrm{II})-\mathrm{Cr}-\mathrm{TiO}_{2}$ & Dark green & 112 & Anatase/Rutile (30) \\
\hline $\mathrm{Pt}(\mathrm{IV})-\mathrm{Cr}-\mathrm{TiO}_{2}$ & Dark green & 108 & Anatase/Rutile (32) \\
\hline $\mathrm{Cr}-\mathrm{V}-\mathrm{TiO}_{2}$ & Brown & 115 & Anatase/Rutile (28) \\
\hline $\mathrm{Pt}(\mathrm{II})-\mathrm{V}-\mathrm{TiO}_{2}$ & Brown & 118 & Anatase/Rutile (24) \\
\hline $\mathrm{Pt}(\mathrm{II})-\mathrm{Ni}-\mathrm{TiO}_{2}$ & Light green & 110 & Anatase (0) \\
\hline $\mathrm{Cr}-\mathrm{Ni}-\mathrm{TiO}_{2}$ & Green & 115 & Anatase (0) \\
\hline
\end{tabular}

XRD patterns of 0.3 at. $\% \mathrm{Pt}(\mathrm{IV})-0.3$ at. $\% \mathrm{Cr}-\mathrm{TiO}_{2}$ and 0.3 at. $\% \mathrm{Cr}-0.3$ at. $\% \mathrm{Ni}^{-\mathrm{TiO}_{2}}$ are shown in Fig. 3 with XRD patterns of each singly-doped $\mathrm{TiO}_{2}$. Crystal structures of all $\mathrm{MM}-\mathrm{TiO}_{2}$ samples are also listed in Table I along with the BET surface areas. Figure 3(a) shows that a rutile phase of $\mathrm{Cr}$ or Pt singly-doped $\mathrm{TiO}_{2}$ was well maintained in doubly-doped $\mathrm{Pt}(\mathrm{IV})-\mathrm{Cr}-\mathrm{TiO}_{2}$ samples. In Fig. 3(b), however, the 0.3 at. $\% \mathrm{Cr}-0.3$ at. $\% \mathrm{Ni}^{-\mathrm{TiO}_{2}}$ sample appears to lack evidence for a rutile phase that was clearly shown in singly-doped 0.3 at. $\% \mathrm{Cr}^{-\mathrm{TiO}_{2}}$. Similarly, 0.3 at.\% $\mathrm{Pt}(\mathrm{II})-0.3$ at. $\% \mathrm{Ni}-\mathrm{TiO}_{2}$ appears to be a pure anatase phase material despite 0.3 at.\% $\mathrm{Pt}(\mathrm{II})$ doping. Therefore, we suggest that codoping with $\mathrm{Ni}$ ions may inhibit the A-R phase transformation in $\mathrm{Cr}-\mathrm{TiO}_{2}$ or $\mathrm{Pt}-\mathrm{TiO}_{2}$.

For comparison, the fraction of rutile, $X_{\mathrm{R}}$, as calculated from the respective peak intensities using the following equation ${ }^{48}$ :

$$
X_{\mathrm{R}}(\%)=\left\{1-\left(1+1.26 I_{\mathrm{R}} / I_{\mathrm{A}}\right)^{-1}\right\} \times 100
$$

where $I_{\mathrm{R}}$ and $I_{\mathrm{A}}$ are the x-ray intensities of the rutile (101) and anatase (110) peaks, respectively. These relative rutile fractions are listed in Table I. These results
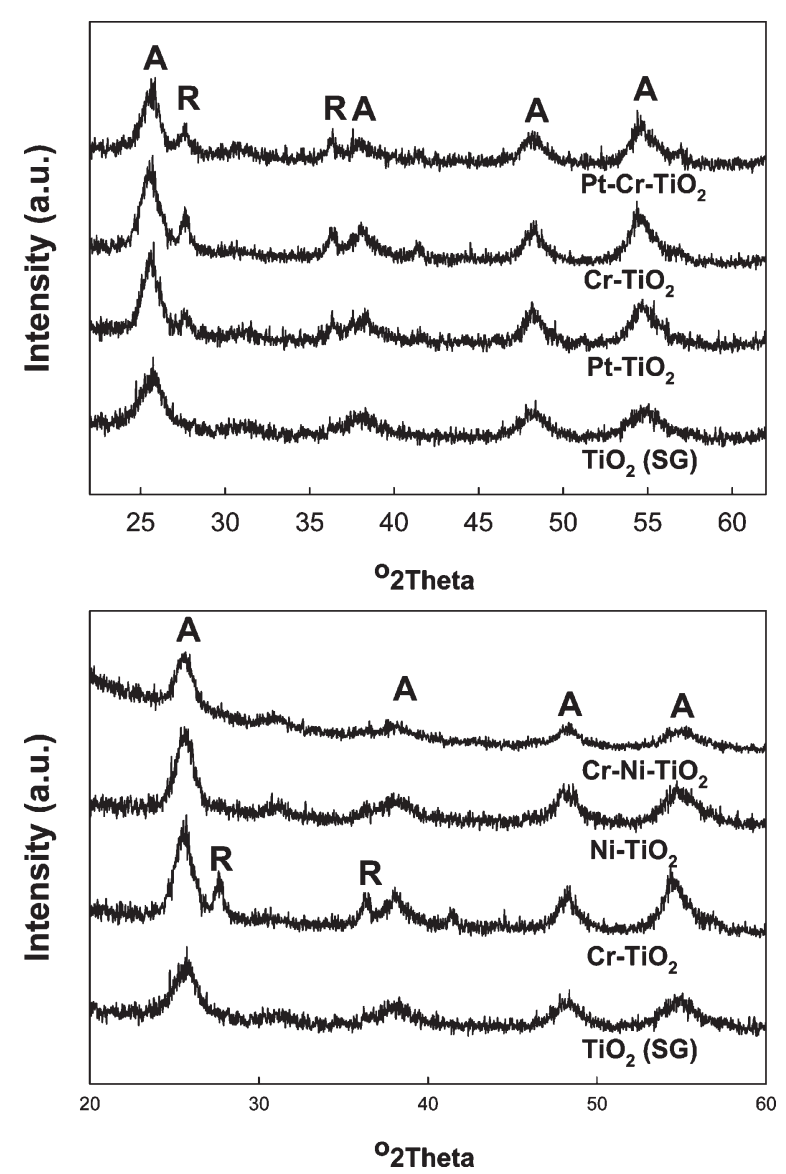

FIG. 3. X-ray diffraction (XRD) pattern measured for 0.3 at.\% Pt-Cr$\mathrm{TiO}_{2}$ and $\mathrm{Cr}-\mathrm{Ni}-\mathrm{TiO}_{2}$ (A: anatase phase, $\mathrm{R}$ : rutile phase). 
show that the fraction of rutile $\left(X_{\mathrm{R}}\right)$ in $\mathrm{MM}-\mathrm{TiO}_{2}$ is not higher than that for each of the $\mathrm{M}-\mathrm{TiO}_{2}$ samples. For example, $X_{\mathrm{R}}$ of 0.3 at.\% $\mathrm{Pt}(\mathrm{IV})-\mathrm{Cr}-\mathrm{TiO}_{2}$ is estimated to be $32 \%$, while $X_{\mathrm{R}}$ of 0.3 at. $\% \mathrm{Pt}(\mathrm{IV})-\mathrm{TiO}_{2}$ and 0.3 at. $\%$ $\mathrm{Cr}-\mathrm{TiO}_{2}$ are estimated as $26 \%$ and $34 \%$, respectively. Furthermore, 0.3 at. $\% \mathrm{Pt}(\mathrm{II})-0.3$ at.\% $\mathrm{V}-\mathrm{TiO}_{2}$ and 0.3 at.\% Cr-0.3 at. $\% \mathrm{~V}-\mathrm{TiO}_{2}$ have similar or smaller $X_{\mathrm{R}}$ values than those of 0.3 at. $\% \mathrm{Pt}(\mathrm{II})-\mathrm{TiO}_{2}, 0.3$ at. $\% \mathrm{~V}-\mathrm{TiO}_{2}$, or 0.3 at.\% $\mathrm{Cr}-\mathrm{TiO}_{2}$.

Figure 4 shows SEM images of 0.3 at.\% Pt- 0.3 at.\% $\mathrm{Cr}^{-} \mathrm{TiO}_{2}$. In Fig. 4(a), 0.3 at.\% Pt(IV)-0.3 at.\% Cr-TiO particles are aggregated together and show rough morphologies. 0.3 at.\% $\mathrm{Pt}(\mathrm{II})-0.3$ at.\% $\mathrm{Cr}-\mathrm{TiO}_{2}$ [Fig. 4(b)] and other $\mathrm{MM}^{-\mathrm{TiO}_{2}}$ (images not shown here) also show SEM images similar to 0.3 at.\% $\mathrm{Pt}(\mathrm{IV})-0.3$ at. $\% \mathrm{Cr}$ $\mathrm{TiO}_{2}$. Niishiro et al. reported that doping with $\mathrm{Sb}^{3+}$ ions in $\mathrm{TiO}_{2}$ suppressed sintering due to the difference in size between $\mathrm{Sb}^{3+}(0.90 \AA)$ and $\mathrm{Ti}^{4+}$, which results in the formation of finer and smoother crystalline particles. ${ }^{28}$ However, in our case, the doping of 0.3 at. $\% \mathrm{Pt}^{2+}$ $(0.94 \AA)$ does not significantly change either the size of particle or the morphology [Fig. 4(b)]. This may be due

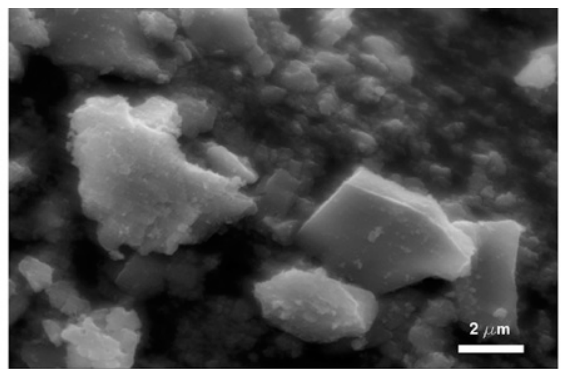

(a)

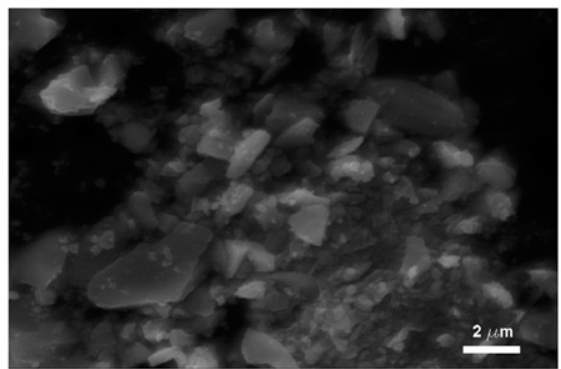

(b)

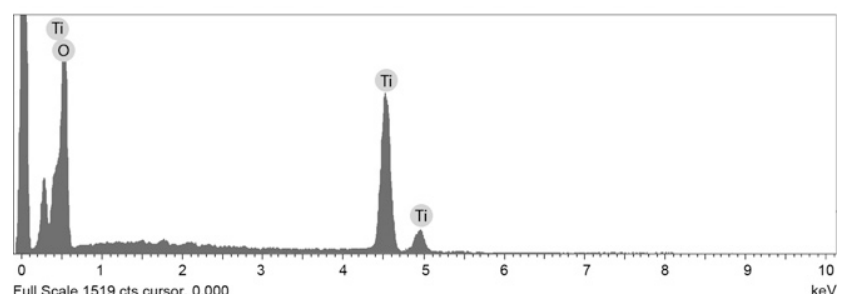

(c)

FIG. 4. SEM images of (a) 0.3 at. $\% \mathrm{Pt}(\mathrm{IV})-\mathrm{Cr}-\mathrm{TiO}_{2}$ and (b) 0.3 at. $\%$ $\mathrm{Pt}(\mathrm{II})-\mathrm{Cr}-\mathrm{TiO}_{2}$, and (c) EDS spectra of $\mathrm{Pt}(\mathrm{II})-\mathrm{Ni}-\mathrm{TiO}_{2}$ that clearly shows dopants signals (i.e., $\mathrm{Pt}$ and $\mathrm{Ni}$ ) other than $\mathrm{Ti}$ and $\mathrm{O}$ signals were not observed. to the relatively low doping level $(0.3 \%$ versus $0.5-2 \%)$ and a lower calcination temperature $\left(400{ }^{\circ} \mathrm{C}\right.$ versus $\left.1150{ }^{\circ} \mathrm{C}\right)$. In addition, the EDS spectrum of 0.3 at. $\%$ $\mathrm{Pt}(\mathrm{II})-0.3$ at.\% $\mathrm{Ni}-\mathrm{TiO}_{2}$ [Fig. 4(c)] shows no apparent signals for $\mathrm{Pt}$ and $\mathrm{Ni}$; only those of $\mathrm{Ti}$ and $\mathrm{O}$ are observed. This indicates that metal ions with larger ionic radii than $\mathrm{Ti}^{4+}$ such as $\mathrm{Pt}^{2+}$ or $\mathrm{Ni}^{2+}$ ions are well incorporated into the $\mathrm{TiO}_{2}$ lattice and not located in the surface region; these results are consistent with XRD results.

There are no significant differences between 0.3 at. $\%$ $\mathrm{Pt}(\mathrm{IV})-0.3$ at. $\% \mathrm{Cr}-\mathrm{TiO}_{2}$ and 0.3 at. $\% \mathrm{Pt}(\mathrm{II})-0.3$ at. $\% \mathrm{Cr}-$ $\mathrm{TiO}_{2}$ in terms of the XRD pattern, BET surface areas, morphology, and element analysis as determined by EDS. However, UV/vis DRS results clearly show the difference between two samples as shown in Fig. 5. 0.3 at.\% Pt(IV)0.3 at. $\% \mathrm{Cr}-\mathrm{TiO}_{2}$ shows an enhanced absorption compared to 0.3 at. $\% \mathrm{Pt}^{-\mathrm{TiO}_{2}}$ or 0.3 at. $\% \mathrm{Cr}-\mathrm{TiO}_{2}$. The spectral response of 0.3 at. $\% \mathrm{Pt}(\mathrm{IV})-0.3$ at. $\% \mathrm{Cr}-\mathrm{TiO}_{2}$ appears to be an addition spectrum of the singly-doped 0.3 at. $\% \mathrm{Pt}$ $\mathrm{TiO}_{2}$ combined with that of 0.3 at.\% Cr-TiO 2 [Fig. 5(a)]. On the other hand, the absorption of 0.3 at. $\% \mathrm{Pt}(\mathrm{II})$ 0.3 at. $\% \mathrm{Cr}-\mathrm{TiO}_{2}$ is almost identical to 0.3 at. $\% \mathrm{Cr}-\mathrm{TiO}_{2}$ [Fig. 5(b)]. Therefore, we expect that absorption of visible light is more efficient in the 0.3 at.\% Pt(IV)- 0.3 at.\%
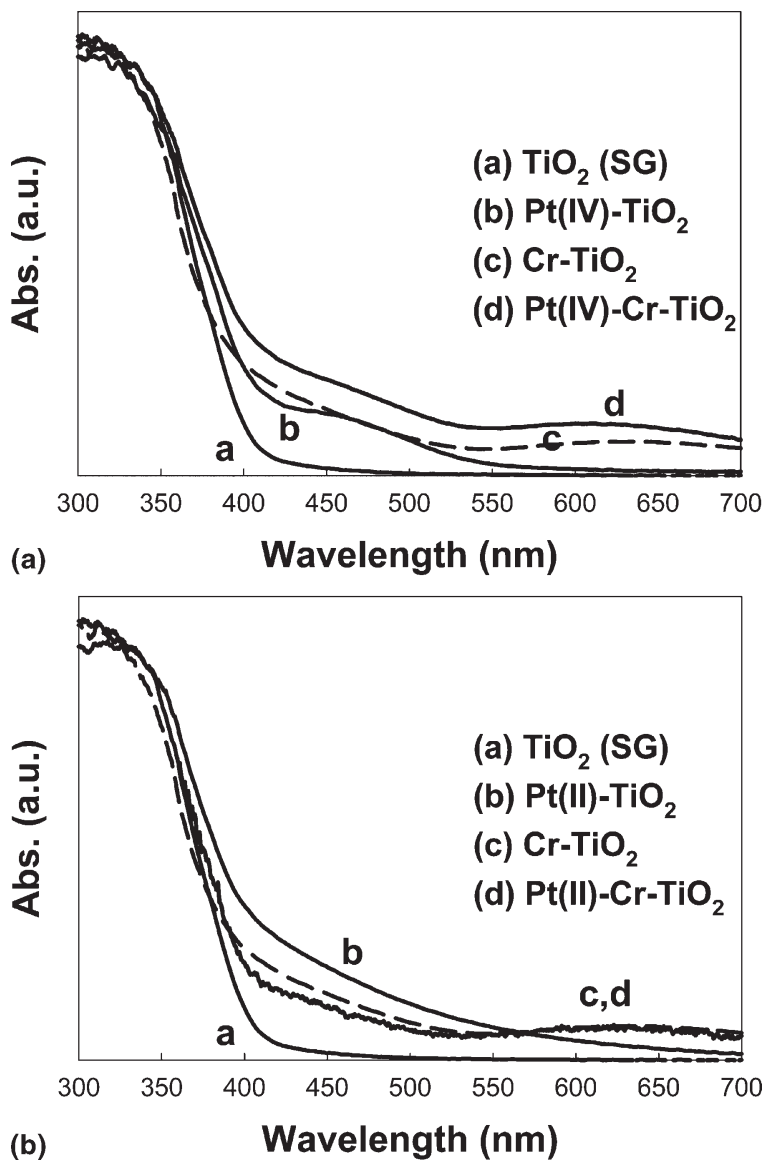

FIG. 5. UV/vis diffuse reflectance spectra (DRS) for 0.3 at.\% Pt-Cr$\mathrm{TiO}_{2}$ : (a) $\mathrm{Pt}(\mathrm{IV})-\mathrm{Cr}-\mathrm{TiO}{ }_{2}$, (b) $\mathrm{Pt}(\mathrm{II})-\mathrm{Cr}-\mathrm{TiO}_{2}$ samples. 

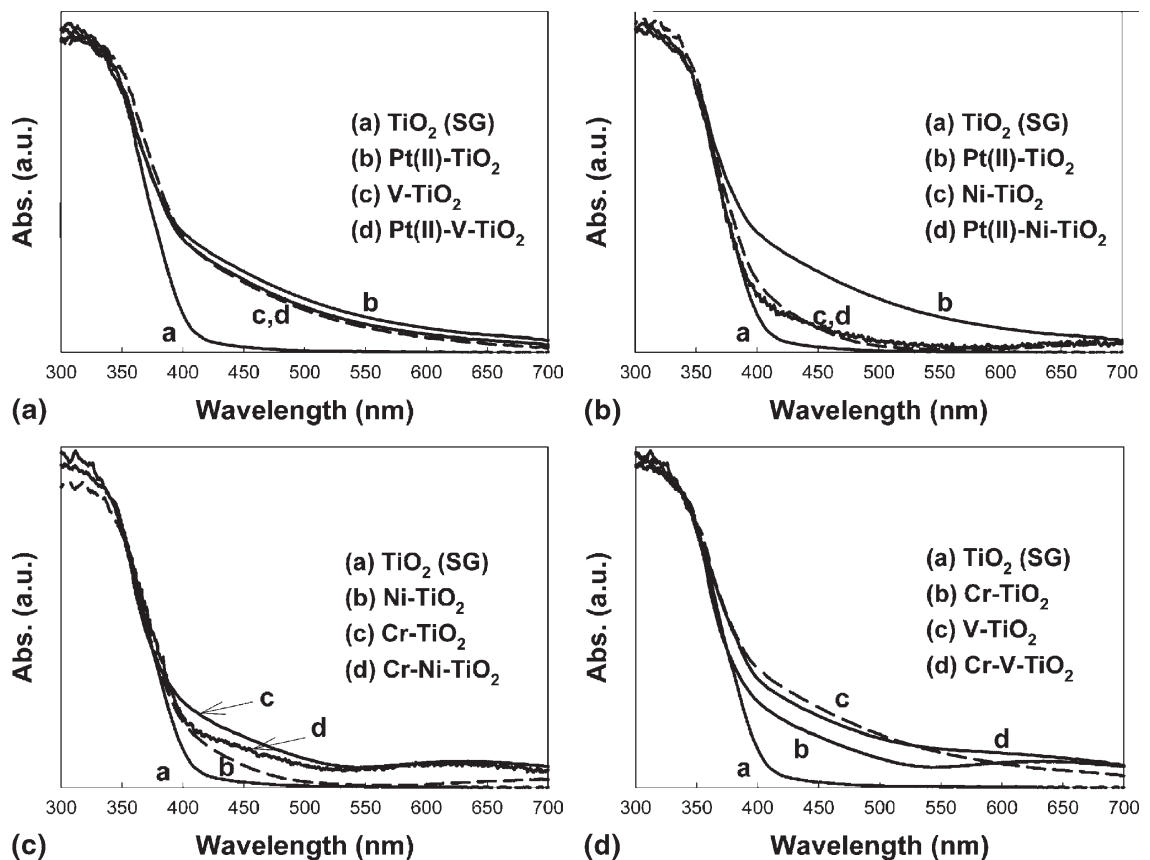

(c)

Wavelength $(\mathrm{nm})$

(d)

Wavelength $(\mathbf{n m})$

FIG. 6. UV/vis diffuse reflectance spectra (DRS) for (a) 0.3 at. $\% \mathrm{Pt}(\mathrm{II})-\mathrm{V}-\mathrm{TiO}_{2}$, (b) 0.3 at. $\% \mathrm{Pt}(\mathrm{II})-\mathrm{Ni}-\mathrm{TiO}{ }_{2}$, (c) 0.3 at. $\%$ Cr-Ni-TiO ${ }_{2}$, and (d) 0.3 at. $\% \mathrm{Cr}-\mathrm{V}-\mathrm{TiO}_{2}$.

Cr- $\mathrm{TiO}_{2}$ samples than the singly-doped 0.3 at.\% Pt(IV)$\mathrm{TiO}_{2}$ samples.

Figure 6 shows UV/vis DRS results for other doublydoped $\mathrm{MM}-\mathrm{TiO}_{2}$ materials. The absorption spectra of the 0.3 at. $\% \mathrm{Pt}(\mathrm{II})-0.3$ at. $\% \mathrm{~V}-\mathrm{TiO}_{2}$ sample [Fig. 6(a)] and the 0.3 at. $\% \mathrm{Pt}(\mathrm{II})-0.3$ at. $\% \mathrm{Ni}^{-\mathrm{TiO}_{2}}$ sample [Fig. 6(b)] were the same as those of 0.3 at.\% singly-doped $\mathrm{V}-\mathrm{TiO}_{2}$ and $\mathrm{Ni}-\mathrm{TiO}_{2}$ samples, respectively. In all the cases of $\mathrm{Pt}(\mathrm{II})-\mathrm{M}-\mathrm{TiO}_{2}$, the $\mathrm{Pt}$ (II) is not attributed to the absorption spectra of the codoped $\mathrm{TiO}_{2}$. In contrast, $\mathrm{Pt}(\mathrm{IV})$ is the only effective codopant for enhanced visible light absorption in the $\mathrm{Cr}-\mathrm{M}-\mathrm{TiO}_{2}$ samples. For example, 0.3 at. $\% \mathrm{Cr}-0.3$ at. $\% \mathrm{Ni}^{-\mathrm{TiO}_{2}}$ [Fig. 6(c)] and 0.3 at.\% $\mathrm{Cr}-0.3$ at.\% $\mathrm{V}-\mathrm{TiO}_{2}$ [Fig. 6(d)] does not show enhanced absorption compared to the sum of singly-doped $\mathrm{TiO}_{2}$, while 0.3 at. $\% \mathrm{Cr}-0.3$ at. $\% \mathrm{Pt}(\mathrm{IV})-\mathrm{TiO}_{2}$ has a significantly enhanced absorption in the visible region [Fig. 5(a)].

\section{Visible light photocatalytic activity}

Figure 7 shows visible light photocatalytic activities of various $\mathrm{M}-\mathrm{TiO}_{2}$ and $\mathrm{MM}-\mathrm{TiO}_{2}$ preparations for the degradation of methylene blue (MB) in aqueous solution. The degradation and bleaching reaction follow apparent first-order kinetics. Under visible light irradiation at $\lambda>400 \mathrm{~nm}$, direct photolysis of $\mathrm{MB}$ is observed in the absence of $\mathrm{TiO}_{2}$ particles since $\mathrm{MB}$ molecules can absorb visible light and become photolyzed without the photocatalyst. The measured first-order rate constant, $k_{\mathrm{MB}}$, increases slightly in the presence of undoped $\mathrm{TiO}_{2}$. This increase may be due to additional light absorption

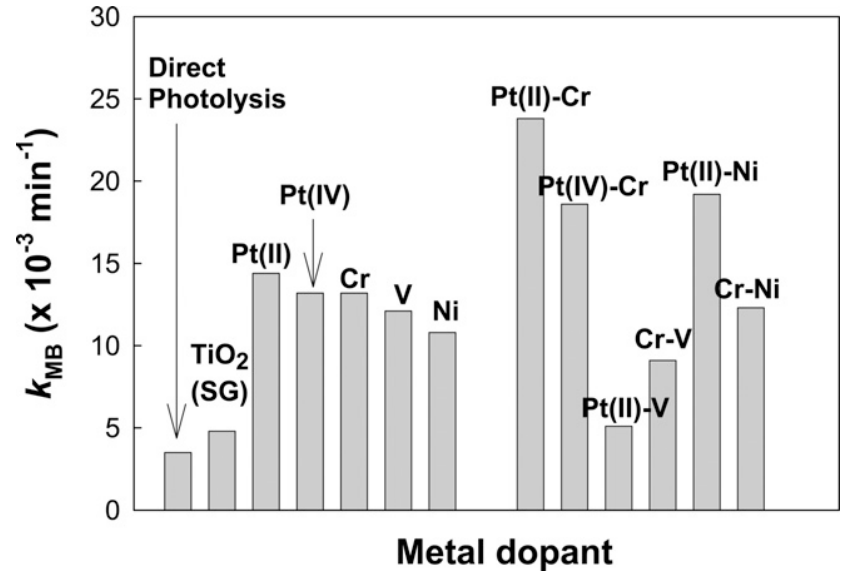

FIG. 7. The comparison of degradation rate constant $\left(k_{\mathrm{MB}}\right)$ of $\mathrm{MB}$ for various single-doped or codoped $\mathrm{TiO}_{2}$ samples ( 0.3 at.\% doping).

above $400 \mathrm{~nm}$ by the $\mathrm{TiO}_{2}$ particles or by an enhanced electron transfer from $\mathrm{MB}$ to the conduction band of $\mathrm{TiO}_{2}$. All the singly-doped $\mathrm{M}-\mathrm{TiO}_{2}$ preparations show visible light photocatalytic activity for $\mathrm{MB}$ degradation while the 0.3 at.\% $\mathrm{Pt}(\mathrm{II})-\mathrm{TiO}_{2}$ samples give the highest values for $k_{\mathrm{MB}}$. Among doubly-doped $\mathrm{MM}-\mathrm{TiO}_{2}$ samples, only 0.3 at.\% $\mathrm{Pt}-0.3$ at. $\% \mathrm{Cr}^{-\mathrm{TiO}}{ }_{2}$ [both $\mathrm{Pt}(\mathrm{IV})$ and $\mathrm{Pt}(\mathrm{II})]$ and $\mathrm{Pt}(\mathrm{II})-\mathrm{Ni}-\mathrm{TiO}_{2}$ show higher $k_{\mathrm{MB}}$ values than those measured for the singly-doped $\mathrm{TiO}_{2}$ samples. Therefore, codoping with Pt appears to be effective for enhancing the visible light degradation of MB degradation. On the other hand, the doubly-doped Pt-V-TiO samples have lower photocatalytic activity, which may be due to the effect of $\mathrm{V}$ doping. 
0.3 at. $\% \mathrm{Pt}(\mathrm{IV})-0.3$ at. $\% \mathrm{Cr}-\mathrm{TiO}_{2}$, which has enhanced visible light absorption [Fig. 5(a)], is less photoactive than 0.3 at. $\% \mathrm{Pt}(\mathrm{II})-0.3$ at. $\% \mathrm{Cr}-\mathrm{TiO}_{2}$. Conversely, 0.3 at. $\% \mathrm{Cr}-0.3$ at. $\% \mathrm{~V}-\mathrm{TiO}_{2}$ and 0.3 at. $\% \mathrm{Pt}(\mathrm{II})-0.3$ at. $\%$ $\mathrm{V}-\mathrm{TiO}_{2}$ have significantly decreased $k_{\mathrm{MB}}$ values compared to their singly-doped $\mathrm{TiO}_{2}$ counterparts. In comparison to the 0.3 at. $\% \mathrm{Cr}-0.3$ at. $\% \mathrm{Ni}-\mathrm{TiO}_{2}$ and 0.3 at. $\%$ $\mathrm{Pt}(\mathrm{II})-0.3$ at. $\%$ Ni-TiO ${ }_{2}$ samples, $\mathrm{V}$ codoping of $\mathrm{Cr}-\mathrm{TiO}_{2}$ and $\mathrm{Pt}-\mathrm{TiO}_{2}$ show a net negative effect on photocatalytic activity. However, these samples still show better photocatalytic activity than undoped $\mathrm{TiO}_{2}$.

The photocatalytic oxidation of iodide ions $\left(\mathrm{I}^{-}\right)$can also be used to compare the visible light photocatalytic activities of various $\mathrm{MM}-\mathrm{TiO}_{2}$ preparations. Iodide in aqueous solution is readily oxidized to tri-iodide $\left(\mathrm{I}_{3}{ }^{-}\right)$ according to the following reaction:

$$
I^{-}+h_{\mathrm{vb}}^{+} \longrightarrow I \stackrel{+I}{\longrightarrow} I_{2} \stackrel{+I^{-}}{\longrightarrow} I_{3}^{-} .
$$

Figure 8 shows the production of $\mathrm{I}_{3}{ }^{-}$ions from $\mathrm{I}^{-}$ oxidation under visible light irradiation in the presence of doubly-doped $\mathrm{MM}-\mathrm{TiO}_{2}$ materials. As a control measurement, no $\mathrm{I}_{3}{ }^{-}$is produced in the absence of $\mathrm{TiO}_{2}$ particles at $\lambda>400 \mathrm{~nm}$. Undoped $\mathrm{TiO}_{2}, 0.3$ at. $\%$ $\mathrm{V}-\mathrm{TiO}_{2}$, and 0.3 at. $\% \mathrm{Pt}(\mathrm{II})-\mathrm{TiO}_{2}$ show little photocatalytic activity with respect to the net photooxidation of $\mathrm{I}^{-}$ to $\mathrm{I}_{3}{ }^{-}$. However, 0.3 at.\% $\mathrm{V}-0.3$ at. $\% \mathrm{Cr}-\mathrm{TiO}_{2}$ and 0.3 at. $\%$ $\mathrm{Pt}(\mathrm{II})-0.3$ at. $\% \mathrm{Cr}-\mathrm{TiO}_{2}$ have higher photoactivity. Therefore, $\mathrm{Cr}$ is clearly an effective codopant with respect to $\mathrm{I}^{-}$ photooxidation in the visible spectrum. $\mathrm{I}_{3}{ }^{-}$production is very fast during the initial phases of the reaction, but it slows noticeably as irradiation continues. This is due to the back photoreaction of $\mathrm{I}_{3}{ }^{-}$with conduction-band electrons to reform $\mathrm{I}^{-}$ions. The back reaction effectively competes with the forward reaction of iodide with valence-band holes or surface hydroxyl radicals as the concentration of $\mathrm{I}_{3}{ }^{-}$increases with time.

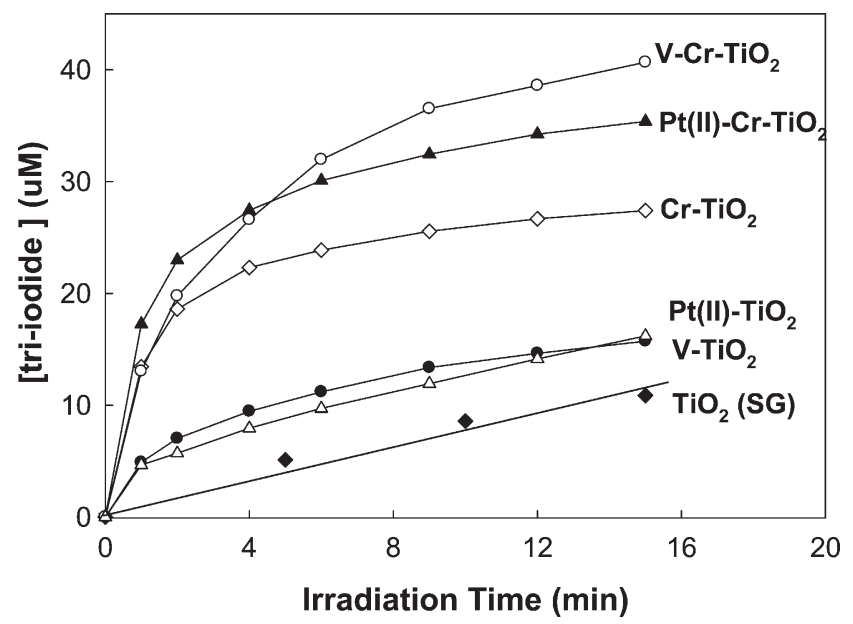

FIG. 8. The production of tri-iodide by iodide oxidation $\left(\left[\mathrm{I}^{-}\right]_{0}=\right.$ $50 \mathrm{mM}$, total volume $=30 \mathrm{~mL})$ with selected $\mathrm{MM}-\mathrm{TiO}_{2}(0.3$ at. $\%$ doping level, $1 \mathrm{~g} / \mathrm{L})$ under visible light irradiation $(500 \mathrm{~W},>400 \mathrm{~nm})$.
In Fig. 9, the photocatalytic activity of the singlydoped $\mathrm{M}-\mathrm{TiO}_{2}$ samples and the doubly-doped $\mathrm{MM}$ $\mathrm{TiO}_{2}$ samples are compared in terms of total amount of $\mathrm{I}_{3}{ }^{-}$ions produced during $15 \mathrm{~min}$ of irradiation. Similar to $\mathrm{MB}$ degradation, all the $\mathrm{M}-\mathrm{TiO}_{2}$ samples improve the $\mathrm{I}^{-}$oxidation rates; 0.3 at. $\% \mathrm{Pt}(\mathrm{IV})-\mathrm{TiO}_{2}$ and 0.3 at. $\% \mathrm{Cr}$ $\mathrm{TiO}_{2}$ show the highest activity. However, 0.3 at.\% Pt(II)$\mathrm{TiO}_{2}, 0.3$ at. $\% \mathrm{~V}-\mathrm{TiO}_{2}$, and 0.3 at. $\% \mathrm{Ni}-\mathrm{TiO}_{2}$, which have comparable activities to 0.3 at. $\% \mathrm{Pt}(\mathrm{IV})-\mathrm{TiO}_{2}$ or 0.3 at.\% $\mathrm{Cr}-\mathrm{TiO}_{2}$ in terms of $\mathrm{MB}$ degradation, show only slightly enhanced $\mathrm{I}^{-}$oxidation rates. Most of the $\mathrm{MM}^{-\mathrm{TiO}_{2}}$ samples also show some enhanced photocatalytic activity. 0.3 at.\% $\mathrm{Pt}(\mathrm{II})-0.3$ at. $\% \mathrm{~V}-\mathrm{TiO}_{2}$ has the least visible light activity among the doubly-doped $\mathrm{MM}-\mathrm{TiO}_{2}$ samples.

The doping level of each dopant in $\mathrm{Pt}(\mathrm{II})-\mathrm{Cr}-\mathrm{TiO}_{2}$ is also optimized. Table II shows photocatalytic activities of $\mathrm{Pt}(\mathrm{II})-\mathrm{Cr}-\mathrm{TiO}_{2}$ with different concentrations of $\mathrm{Pt}$ and $\mathrm{Cr}$ over the range of $0.1-0.5$ at.\%. The optimal concentration for increased photocatalytic activity is 0.3 at. $\%$ $\mathrm{Pt}(\mathrm{II})$ and 0.3 at.\% Cr. It is also observed that photocatalytic activity with respect to $\mathrm{I}^{-}$oxidation strongly depends on $\mathrm{Cr}$ concentration.

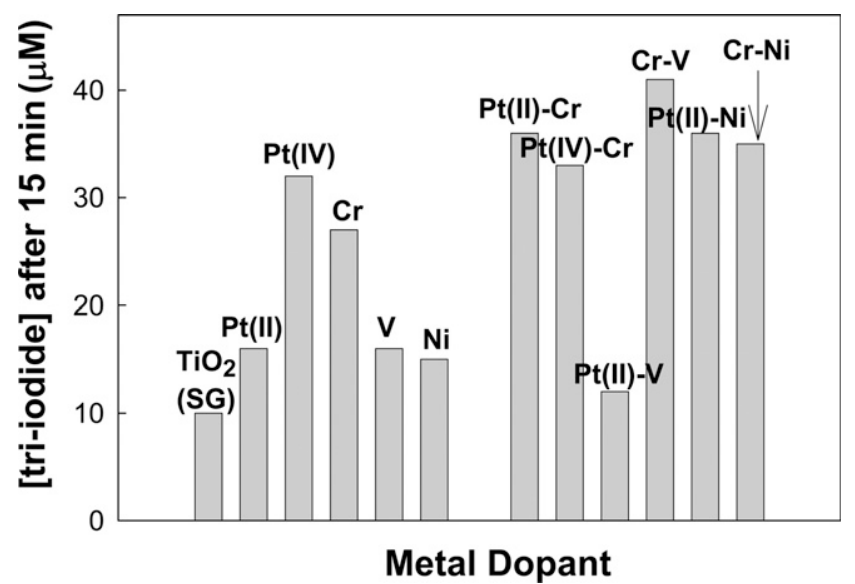

FIG. 9. The comparison of various single-doped or co-doped $\mathrm{TiO}_{2}$ samples ( 0.3 at.\% doping) for $\mathrm{I}^{-}$oxidation.

TABLE II. Photocatalytic activities of $\mathrm{Pt}(\mathrm{II})-\mathrm{Cr}-\mathrm{TiO}_{2}$ with different doping level for I oxidation under visible-light irradiation $(>400 \mathrm{~nm})$.

\begin{tabular}{lc}
\hline \hline \multicolumn{1}{c}{ Sample } & {$\left[\mathrm{I}^{3-}\right]$ produced $(\mu \mathrm{M})$ after $15 \mathrm{~min}$} \\
\hline $0.3 \% \mathrm{Pt}(\mathrm{II})$ with & \\
$0 \% \mathrm{Cr}$ & 16 \\
$0.1 \% \mathrm{Cr}$ & 19 \\
$0.2 \% \mathrm{Cr}$ & 21 \\
$0.3 \% \mathrm{Cr}$ & 36 \\
$0.5 \% \mathrm{Cr}$ & 32 \\
$0.3 \% \mathrm{Cr}$ with & \\
$0 \% \mathrm{Pt}$ & 29 \\
$0.1 \% \mathrm{Pt}$ & 31 \\
$0.2 \% \mathrm{Pt}$ & 28 \\
$0.3 \% \mathrm{Pt}$ & 36 \\
$0.5 \% \mathrm{Pt}$ & 32 \\
\hline \hline
\end{tabular}


The photocatalytic degradation of phenol under visible light irradiation is shown in Fig. 10. Phenol is degraded effectively with $\mathrm{Pt}-\mathrm{TiO}_{2}$ [both $\mathrm{Pt}(\mathrm{IV})-\mathrm{TiO}_{2}$ and $\mathrm{Pt}(\mathrm{II})-$ $\mathrm{TiO}_{2}$ ] and totally degraded within $2 \mathrm{~h}$ with 0.3 at. $\%$ $\mathrm{Pt}(\mathrm{IV})-\mathrm{TiO}_{2}$. However, 0.3 at.\% Pt-0.3 at.\% $\mathrm{Cr}-\mathrm{TiO}_{2}$ does not exhibit any enhancement in the photodegradation of phenol [Fig. 10(a)]. Phenol degradation with 0.3 at. $\% \mathrm{Pt}(\mathrm{IV})-\mathrm{TiO}_{2}$ is slightly decreased by $\mathrm{Cr}$ codoping. Moreover, the resultant photocatalytic activity of 0.3 at.\% $\mathrm{Pt}(\mathrm{II})-0.3$ at. $\% \mathrm{Cr}^{-} \mathrm{TiO}_{2}$ is much less than 0.3 at. $\% \mathrm{Pt}(\mathrm{II})-$ $\mathrm{TiO}_{2}$. Similarly, there is no advantage shown by the doubly-doped $\mathrm{Cr}-\mathrm{V}-\mathrm{TiO}_{2}$ samples [Fig. 10(b)]. The other doubly-doped $\mathrm{MM}-\mathrm{TiO}_{2}$ samples, which are not shown here, also have negative codoping effects with respect to phenol degradation. These results clearly indicate that the codoping effects on $\mathrm{TiO}_{2}$ photocatalytic activity are substrate-dependent. Several doubly-doped $\mathrm{MM}-\mathrm{TiO}_{2}$ samples show enhanced photocatalytic activity for MB degradation or $\mathrm{I}^{-}$oxidation. For example, 0.3 at.\% $\mathrm{Pt}(\mathrm{II})$ 0.3 at. $\% \mathrm{Cr}-\mathrm{TiO}_{2}$ and 0.3 at. $\% \mathrm{Cr}-0.3$ at. $\% \mathrm{~V}-\mathrm{TiO}_{2}$ show the highest visible light photocatalytic activity for $\mathrm{MB}$ degradation and $\mathrm{I}^{-}$oxidation, respectively. However, there is no apparent enhancement observed for doublydoped $\mathrm{TiO}_{2}$ materials for phenol photodegradation.
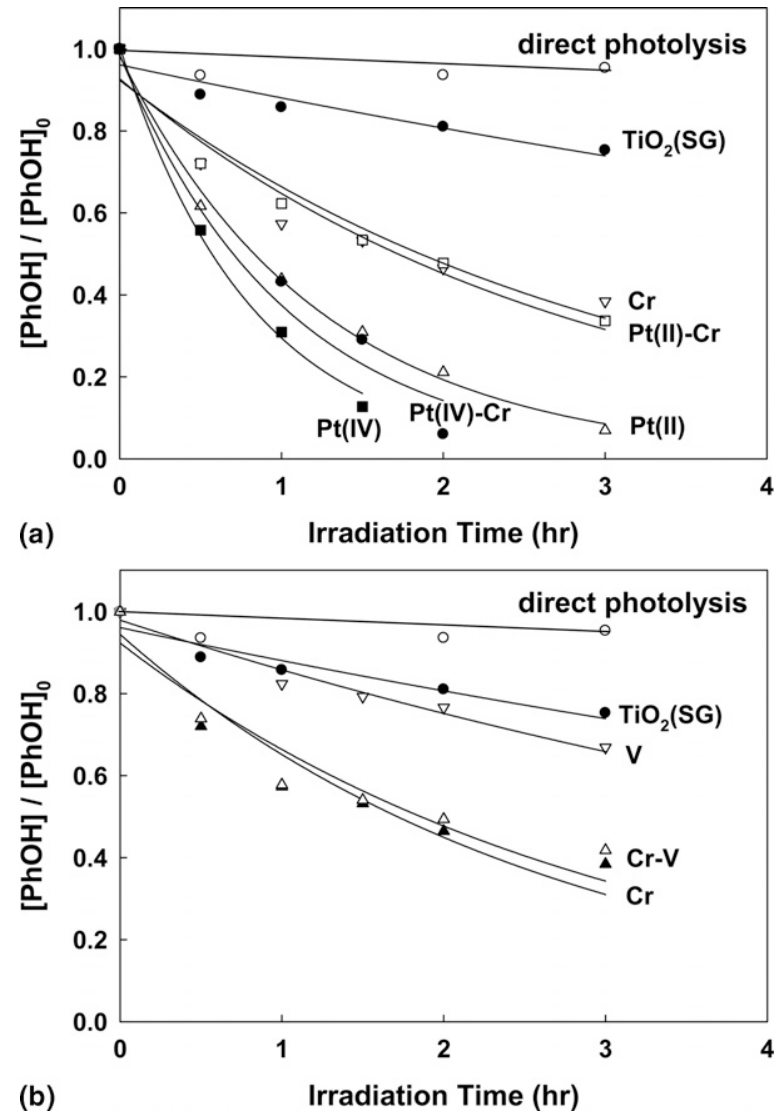

FIG. 10. The degradation of phenol ([phenol $]_{0}=50 \mu \mathrm{M}, 1 \mathrm{~g} / \mathrm{L}$ of 0.3 at. $\%$ single-doped or codoped $\mathrm{TiO}_{2},>400 \mathrm{~nm}$ ): (a) $\mathrm{Pt}-\mathrm{Cr}-\mathrm{TiO}{ }_{2}$, (b) $\mathrm{Cr}-\mathrm{V}-\mathrm{TiO}_{2}$.
It is worth mentioning that photocatalytic activities of $\mathrm{MM}-\mathrm{TiO}_{2}$ were observed substrate-dependent and are not correlated with any physicochemical property of $\mathrm{MM}-\mathrm{TiO}_{2}$. Neither the absorption spectra in the visible region nor the crystal structures (anatase and rutile) of $\mathrm{MM}-\mathrm{TiO}_{2}$ appear to play an important role in the visible light induced photocatalytic reactions. For example, $\mathrm{Pt}(\mathrm{IV})-\mathrm{Cr}-\mathrm{TiO}_{2}$, which was expected to have more efficient absorption of visible light than $\mathrm{Pt}(\mathrm{II})-\mathrm{Cr}-\mathrm{TiO}{ }_{2}$, shows less photocatalytic activity than $\mathrm{Pt}(\mathrm{II})-\mathrm{Cr}-\mathrm{TiO}_{2}$ for both $\mathrm{MB}$ degradation and $\mathrm{I}^{-}$oxidation. However, $\mathrm{Pt}(\mathrm{IV})-\mathrm{Cr}-\mathrm{TiO}_{2}$ shows higher photocatalytic activity than $\mathrm{Pt}(\mathrm{II})-\mathrm{Cr}-\mathrm{TiO}_{2}$ for phenol degradation. In addition, $\mathrm{Pt}(\mathrm{II})-\mathrm{V}-\mathrm{TiO}_{2}$ that has larger visible light absorption than $\mathrm{Pt}(\mathrm{II})-\mathrm{Ni}-\mathrm{TiO}_{2}$ is less photoactive for $\mathrm{MB}$ degradation and $\mathrm{I}^{-}$oxidation, as well. Similarly, the structure (i.e., the fraction of rutile) in $\mathrm{MM}-\mathrm{TiO}_{2}$ does not affect the visible light photocatalytic activity of $\mathrm{MM}-\mathrm{TiO}_{2}$. $\mathrm{Pt}(\mathrm{IV})-\mathrm{Cr}-\mathrm{TiO}_{2}$ with a high relative rutile content and $\mathrm{Pt}(\mathrm{II})-\mathrm{Ni}-\mathrm{TiO}_{2}$ with no rutile at all show comparable photocatalytic activity for $\mathrm{MB}$ degradation. For $\mathrm{I}^{-}$oxidation, $\mathrm{Pt}(\mathrm{II})-\mathrm{Ni}-\mathrm{TiO}_{2}$ and $\mathrm{Cr}-\mathrm{Ni}-\mathrm{TiO}_{2}$ also show comparable photocatalytic activity to $\mathrm{Pt}(\mathrm{II})-\mathrm{Cr}-\mathrm{TiO}_{2}$.

\section{CONCLUSION}

$\mathrm{TiO}_{2}$ codoped with two metal ions was prepared by adding $\mathrm{Pt}\left(\mathrm{Pt}^{4+}\right.$ and $\left.\mathrm{Pt}^{2+}\right), \mathrm{Cr}^{3+}, \mathrm{V}^{3+}$, and $\mathrm{Ni}^{2+}$ ions during sol-gel synthesis. The metal ion dopants used in this study are effectively incorporated into the $\mathrm{TiO}_{2}$ lattice either in Ti(IV) sites or in interstitial sites. Single and double ion doping changes some of the physicochemical properties such as the reactive surface area and photophysical response of pristine $\mathrm{TiO}_{2} .0 .3$ at.\% Pt-0.3 at.\% $\mathrm{Cr}-\mathrm{TiO}_{2}$ (both $\mathrm{Pt}^{4+}$ and $\mathrm{Pt}^{2+}$ ), 0.3 at.\% $\mathrm{Cr}-0.3$ at.\% $\mathrm{V}-\mathrm{TiO}_{2}$, and 0.3 at.\% Pt-0.3 at.\% $\mathrm{V}-\mathrm{TiO}_{2}$ samples lower the A-R phase-transformation temperature since an individual dopant used for codoping also has an enhancing effect on A-R phase transformation. However, 0.3 at.\% Pt- 0.3 at.\% $\mathrm{Ni}-\mathrm{TiO}_{2}$ and 0.3 at. $\%$ Cr- 0.3 at. $\% \mathrm{Ni}-\mathrm{TiO}_{2}$ remain strictly in the anatase phase due to $\mathrm{Ni}$ codoping although doping with $\mathrm{Pt}$ and $\mathrm{Cr}$ alone accelerate A-R phase transformation. All codoped $\mathrm{TiO}_{2}$ materials give extended UV-vis absorption between 400 and $700 \mathrm{~nm}$, but only 0.3 at.\% Pt (IV)-0.3 at.\% $\mathrm{Cr}-\mathrm{TiO}_{2}$ enhanced visible light absorption compared to singly-doped $\mathrm{TiO}_{2}$. Visible light photocatalytic activities are evaluated for the degradation of $\mathrm{MB}$, phenol, and the oxidation of $\mathrm{I}^{-}$in aqueous solution. The photocatalytic activities of codoped $\mathrm{TiO}_{2}$ strongly depends on the nature of the electron-donating substrate and are not correlated with any physicochemical property of the codoped $\mathrm{TiO}_{2}$. Pt-Cr-TiO 2 and Pt-Ni-TiO ${ }_{2}$ enhance the rate of $\mathrm{MB}$ degradation while $\mathrm{Pt}-\mathrm{Cr}-\mathrm{TiO}{ }_{2}, \mathrm{Cr}-\mathrm{V}-\mathrm{TiO}_{2}$, $\mathrm{Pt}-\mathrm{Ni}-\mathrm{TiO}_{2}$, and $\mathrm{Cr}-\mathrm{Ni}-\mathrm{TiO}_{2}$ show enhanced activity for $\mathrm{I}^{-}$oxidation. However, none of the codoped samples 
show enhanced photocatalytic activity for phenol degradation compared to their singly-doped $\mathrm{TiO}_{2}$ counterparts. All codoped $\mathrm{TiO}_{2}$ samples exhibit some enhancement in photocatalytic activity for all three reactions compared to undoped nanoparticulate $\mathrm{TiO}_{2}$.

\section{ACKNOWLEDGMENTS}

We gratefully acknowledge the generous support for this research that has been provided by the NorthropGrumman Corporation. In particular, we would like to give special credit to Dr. Ronald Pirich for his enthusiastic encouragement and intellectual support for our joint projects over the years.

\section{REFERENCES}

1. R. Asahi, T. Morikawa, T. Ohwaki, K. Aoki, and Y. Taga: Visible-light photocatalysis in nitrogen-doped titanium oxides. $\underline{\text { Sci- }}$ ence 293, 269 (2001).

2. M. Mrowetz, W. Balcerski, A.J. Colussi, and M.R. Hoffman: Oxidative power of nitrogen-doped $\mathrm{TiO}_{2}$ photocatalysts under visible illumination. J. Phvs. Chem. B 108, 17269 (2004).

3. G. Sauthier, E. Gyorgy, and A. Figueras: Investigation of nitrogen-doped $\mathrm{TiO}_{2}$ thin films grown by reactive pulsed laser deposition. J. Mater. Res. 23, 2340 (2008).

4. T. Umebayashi, T. Yamaki, S. Tanaka, and K. Asai: Visible lightinduced degradation of methylene blue on S-doped $\mathrm{TiO}_{2}$. Chem. Lett. 32, 330 (2003).

5. W.Y. Su, Y.F. Zhang, Z.H. Li, L. Wu, X.X. Wang, J.Q. Li, and X.Z. Fu: Multivalency iodine doped $\mathrm{TiO}_{2}$ : Preparation, characterization, theoretical studies, and visible-light photocatalysis. Langmuir 24, 3422 (2008).

6. G. Liu, Z.G. Chen, C.L. Dong, Y.N. Zhao, F. Li, G.Q. Lu, and H.M. Cheng: Visible light photocatalyst: Iodine-doped mesoporous titania with a bicrystalline framework. J. Phys. Chem. B 110, 20823 (2006).

7. X.T. Hong, Z.P. Wang, W.M. Cai, F. Lu, J. Zhang, Y.Z. Yang, N. Ma, and Y.J. Liu: Visible-light-activated nanoparticle photocatalyst of iodine-doped titanium dioxide. Chem. Mater. 17, 1548 (2005).

8. J.K. Zhou, L. Lv, J.Q. Yu, H.L. Li, P.Z. Guo, H. Sun, and X.S. Zhao: Synthesis of self-organized polycrystalline F-doped $\mathrm{TiO}_{2}$ hollow microspheres and their photocatalytic activity under visible light. J.Phvs. Chem. C 112, 5316 (2008).

9. X.W. Zhang and L.C. Lei: One step preparation of visible-light responsive $\mathrm{Fe}-\mathrm{TiO}_{2}$ coating photocatalysts by MOCVD. Mater. Lett. 62, 895 (2008).

10. X.W. Zhang, M.H. Zhou, and L.C. Lei: Co-deposition of photocatalytic Fe doped $\mathrm{TiO}_{2}$ coatings by MOCVD. Catal. Commun. 7. 427 (2006).

11. W.Y. Teoh, R. Amal, L. Madler, and S.E. Pratsinis: Flame sprayed visible light-active $\mathrm{Fe}-\mathrm{TiO}_{2}$ for photomineralisation of oxalic acid. Catal. Todav 120, 203 (2007).

12. K. Iketani, R.D. Sun, M. Toki, K. Hirota, and O. Yamaguchi: Solgel-derived $\mathrm{V}_{x} \mathrm{Ti}_{1-x} \mathrm{O}_{2}$ films and their photocatalytic activities under visible light irradiation. Mater. Sci. Eng. B 108, 187 (2004).

13. S. Klosek and D. Raftery: Visible light driven V-doped $\mathrm{TiO}_{2}$ photocatalyst and its photooxidation of ethanol. I.Phvs. Chem. B 105, 2815 (2001).

14. J.C.S. Wu and C.H. Chen: A visible-light response vanadiumdoped titania nanocatalyst by sol-gel method. J. Photochem. Photobiol., A 163, 509 (2004).
15. E. Borgarello, J. Kiwi, M. Gratzel, E. Pelizzetti, and M. Visca: Visible-light induced water cleavage in colloidal solutions of chromium-doped titanium-dioxide particles. J. Am. Chem. Soc. 104, 2996 (1982).

16. M. Anpo, Y. Ichihashi, M. Takeuchi, and H. Yamashita: Design and development of unique titanium oxide photocatalysts capable of operating under visible light irradiation by an advanced metal ion-implantation method. Sci. Technol. Catal. 121, 305 (1999).

17. D.H. Kim, K.S. Lee, Y.S. Kim, Y.C. Chung, and S.J. Kim: Photocatalytic activity of $\mathrm{Ni} 8 \mathrm{wt} \%$-doped $\mathrm{TiO}_{2}$ photocatalyst synthesized by mechanical alloying under visible light. $\underline{\text { J. Am. Ceram. }}$ Soc. 89, 515 (2006).

18. S. Kim, S.J. Hwang, and W.Y. Choi: Visible light active platinumion-doped $\mathrm{TiO}_{2}$ photocatalyst. J.Phvs. Chem. B 109. 24260 (2005).

19. H. Park, W. Choi, and M.R. Hoffmann: Effects of the preparation method of the ternary $\mathrm{CdS} / \mathrm{TiO}_{2} / \mathrm{Pt}$ hybrid photocatalysts on visible light-induced hydrogen production. J. Mater. Chem. 18, 2379 (2008).

20. E. Bae and W. Choi: Highly enhanced photoreductive degradation of perchlorinated compounds on dye-sensitized metal/ $/ \mathrm{TiO}_{2}$ under visible light. Environ. Sci. Technol. 37, 147 (2003).

21. W.Y. Choi, A. Termin, and M.R. Hoffmann: The role of metalion dopants in quantum-sized $\mathrm{TiO}_{2}$ - Correlation between photoreactivity and charge-carrier recombination dynamics. $\underline{J \text {. Phvs. }}$ Chem. 98, 13669 (1994).

22. J.H. Chen, M.S. Yao, and X.L. Wang: Investigation of transition metal ion doping behaviors on $\mathrm{TiO}_{2}$ nanoparticles. J. Nano. Res. 10, $163(2008)$.

23. A. Di Paola, E. Garcia-Lopez, S. Ikeda, G. Marci, B. Ohtani, and L. Palmisano: Photocatalytic degradation of organic compounds in aqueous systems by transition metal doped polycrystalline $\mathrm{TiO}_{2}$. Catal. Todav 75, 87 (2002).

24. S.S. Srinivasan, J. Wade, E.K. Stefanakos, and Y. Goswami: Synergistic effects of sulfation and co-doping on the visible light photocatalysis of $\mathrm{TiO}_{2}$. J. Allovs Compd. 424, 322 (2006).

25. A. Ahmad, J.A. Shah, S. Buzby, and S.I. Shah: Structural effects of codoping of $\mathrm{Nb}$ and $\mathrm{Sc}$ in titanium dioxide nanoparticles. Eur. J. Inorg. Chem. 948 (2008).

26. H. Kato and A. Kudo: Visible-light-response and photocatalytic activities of $\mathrm{TiO}_{2}$ and $\mathrm{SrTiO}_{3}$ photocatalysts codoped with antimony and chromium. J. Phys. Chem. B 106, 5029 (2002).

27. R. Niishiro, H. Kato, and A. Kudo: Nickel and either tantalum or niobium-codoped $\mathrm{TiO}_{2}$ and $\mathrm{SrTiO}_{3}$ photocatalysts with visiblelight response for $\mathrm{H}_{2}$ or $\mathrm{O}_{2}$ evolution from aqueous solutions. Phys. Chem. Chem. Phys. 7, 2241 (2005).

28. R. Niishiro, R. Konta, H. Kato, W.J. Chun, K. Asakura, and A. Kudo: Photocatalytic $\mathrm{O}_{2}$ evolution of rhodium and antimonycodoped rutile-type $\mathrm{TiO}_{2}$ under visible light irradiation. $\underline{\text { J.Phvs. }}$ Chem. C 111, 17420 (2007).

29. D.E. Huang, S.J. Liao, S.Q. Quan, L. Liu, Z.J. He, J.B. Wan, and W.B. Zhou: Preparation and characterization of anatase N-Fcodoped $\mathrm{TiO}_{2}$ sol and its photocatalytic degradation for formaldehyde. J. Mater. Res. 22, 2389 (2007).

30. D. Li, H. Haneda, S. Hishita, and N. Ohashi: Visible-light-driven N-F-codoped $\mathrm{TiO}_{2}$ photocatalysts. 1. Synthesis by spray pyrolysis and surface characterization. Chem. Mater. 17, 2588 (2005).

31. J.G. Yu, M.H. Zhou, B. Cheng, and X.J. Zhao: Preparation, characterization and photocatalytic activity of in situ N,S-codoped $\mathrm{TiO}_{2}$ powders. J. Mol. Catal. A: Chem. 246, 176 (2006).

32. H.Y. Liu and L. Gao: (Sulfur,nitrogen)-codoped rutile-titanium dioxide as a visible-light-activated photocatalyst. J. Am. Ceram. Soc. 87, 1582 (2004).

33. Y. Sakatani, H. Ando, K. Okusako, H. Koike, J. Nunoshige, T. Takata, J.N. Kondo, M. Hara, and K. Domen: Metal ion and $\mathrm{N}$ co-doped $\mathrm{TiO}_{2}$ as a visible-light photocatalyst. J. Mater. Res. 19,2100 (2004). 
34. Y. Sakatani, J. Nunoshige, H. Ando, K. Okusako, H. Koike, T. Takata, J.N. Kondo, M. Hara, and K. Domen: Photocatalytic decomposition of acetaldehyde under visible light irradiation over $\mathrm{La}^{3+}$ and $\mathrm{N}$ co-doped $\mathrm{TiO}_{2}$. Chem. Lett. 32, $1156(2003)$.

35. C.C. Pan and J.C.S. Wu: Visible-light response Cr-doped $\mathrm{TiO}_{2-x} \mathrm{~N}_{x}$ photocatalysts. Mater. Chem. Phys. 100, 102 (2006).

36. S. Kim and S-K. Lee: Visible light-induced photocatalytic oxidation of 4-chlorophenol and dichloroacetate in intrided $\mathrm{Pt}_{-} \mathrm{TiO}_{2}$ aqueous suspensions. J. Photochem. Photobiol., A 203, 145 (2009).

37. Z.Y. Zhao and Q.J. Liu: Designed highly effective photocatalyst of anatase $\mathrm{TiO}_{2}$ codoped with nitrogen and vanadium under visible-light irradiation using first-principles. Catal. Lett. 124. 111 (2008).

38. Y. Wang, Y.L. Meng, H.M. Ding, Y.K. Shan, X. Zhao, and X.Z. Tang: A highly efficient visible-light-activated photocatalyst based on bismuth- and sulfur-codoped $\mathrm{TiO}_{2}$. J. Phys. Chem. C 112, 6620 (2008).

39. Z.Q. He, X. Xu, S. Song, L. Xie, J.J. Tu, J.M. Chen, and B. Yan: A visible light-driven titanium dioxide photocatalyst codoped with lanthanum and iodine: An application in the degradation of oxalic acid. J. Phys. Chem. C 112, 16431 (2008).

40. R.D. Shannon: Revised effective ionic-radii and systematic studies of interatomic distances in halides and charcogenides. Acta Crystallogr., Sect. A: Found. Crustallogr. 32, 751 (1976).
41. N. Serpone, D. Lawless, J. Disdier, and J.M. Herrmann: Spectroscopic, photoconductivity, and photocatalytic studies of $\mathrm{TiO}_{2}$ colloid-Naked and with the lattice doped with $\mathrm{Cr}^{3+}, \mathrm{Fe}^{3+}$, and $\mathrm{V}^{5+}$ cations. Langmuir 10, 643 (1994).

42. T. Umebayashi, T. Yamaki, H. Itoh, and K. Asai: Analysis of electronic structures of 3D transition metal-doped $\mathrm{TiO}_{2}$ based on band calculations. J. Phys. Chem. Solids 63, 1909 (2002).

43. A. Kudo, R. Niishiro, A. Iwase, and H. Kato: Effects of doping of metal cations on morphology, activity, and visible light response of photocatalysts. Chem. Phvs. 339, 104 (2007).

44. V.N. Kuznetsov and N. Serpone: Visible light absorption by various titanium dioxide specimens. J. Phvs. Chem. B $\mathbf{1 1 0}$ 25203 (2006).

45. N. Serpone: Is the band gap of pristine $\mathrm{TiO}_{2}$ narrowed by anionand cation-doping of titanium dioxide in second-generation photocatalysts? J. Phvs. Chem. B 110, 24287 (2006).

46. A.A. Lisachenko, V.N. Kuznetsov, M.N. Zakharov, and R.V. Mikhailov: The interaction of $\mathrm{O}_{2}, \mathrm{NO}$, and $\mathrm{N}_{2} \mathrm{O}$ with surface defects of dispersed titanium dioxide. Kinet. Catal. 45, 189 (2004).

47. V.N. Kuznetsov and T.K. Krutitskaya: Nature of color centers in reduced titanium dioxide. Kinet. Catal. 37, 446 (1996).

48. R.A. Spurr and H. Myers: Quantitative analysis of anatase-rutile mixtures with an x-ray diffractometer. Anal. Chem. 29, 760 (1957). 